\title{
PHYSIOLOGICAL STUDIES ON Digitalis lanata L. PLANT BY USING TISSUE CULTURE TECHNIQUE. Nesem, M. ${ }^{1}$; M. Khalil'; Kamilia T. Fouly ${ }^{2}$ and S. Issa ${ }^{2}$ \\ 1- Dept. Agric. Botany, Fac. Agric., Cairo University. \\ 2- National Organization for Drug Control and Research.
}

\begin{abstract}
This experiment was carried out at Department of Biotechnology, tissue culture, green house and farm of Applied Research Center of Medicinal Plants (ARCMP) related to the National Organization for Drug Control and Research (NODCAR) throughout the period from 2005 to 2009 to study the effect of different concentrations of (IBA, NAA, BA and Kin) and their combinations on Digitalis lanata plant. This investigation included four major parts (starting stage, multiplication stage, callus induction stage and rooting stage) as well as Acclimatization stage. The data of this study revealed that in starting stage, MS medium supplemented with $3 \mathrm{mg} / \mathrm{l}$ IBA or with $2 \mathrm{mg} / \mathrm{Kin}+2 \mathrm{mg} / \mathrm{l} \mathrm{IBA}$ gave the best results of survival percentage. The highest number of shoots obtained by explanted cultured on MS medium supplemented with 2 $\mathrm{mg} / \mathrm{l}$ BA. The tallest shoots were obtained by cultured explant on MS medium supplemented with $2 \mathrm{mg} / \mathrm{Kin}, 2 \mathrm{mg} / \mathrm{l} \mathrm{Kin}+2 \mathrm{mg} / \mathrm{I}$ IBA or $3 \mathrm{mg} / \mathrm{l} \mathrm{Kin}+3 \mathrm{mg} / \mathrm{l} \mathrm{IBA}$. MS medium supplemented with $2 \mathrm{mg} / \mathrm{I}$ IBA giving the highest number of leaves per explant. While, in multiplication stage, MS medium supplemented with $0.3 \mathrm{mg} / \mathrm{l} \mathrm{NAA}+$ $0.5 \mathrm{mg} / \mathrm{l} \mathrm{BA}$ gave the highest result of survival percentage. MS medium free hormones gave the tallest shoots, the highest amount of leaf number and root percentage. The highest number of shoots was obtained when cultured explant on MS medium supplemented with $0.4 \mathrm{mg} / \mathrm{l} \mathrm{IBA}+4.0 \mathrm{mg} / \mathrm{l} \mathrm{BA}$. Full MS salt strength medium supplemented with $0.4 \mathrm{mg} / \mathrm{l} \mathrm{NAA}+4.0 \mathrm{mg} / \mathrm{l} \mathrm{Kin}$ gave the highest survival percentage and leaf number. Full MS salt strength medium supplemented with $0.4 \mathrm{mg} / \mathrm{I} I \mathrm{IBA}+4.0$ $\mathrm{mg} / \mathrm{l} \mathrm{BA}$ gave the longest shoots and the highest number of shoots. 3/4 MS salt strength medium supplemented with $0.4 \mathrm{mg} / \mathrm{l}$ IBA $+4.0 \mathrm{mg} / \mathrm{l} \mathrm{Kin}$ or $0.4 \mathrm{mg} / \mathrm{l} \mathrm{IBA}+4.0$ $\mathrm{mg} / \mathrm{l} \mathrm{BA}$ resulted in the highest root percentage. In callus induction stage, MS medium supplemented with 2 and $3 \mathrm{mg} / \mathrm{l}$ 2,4 D. with or without MnSO4 gave 100\% survival percentage. The highest callus dry weight was obtained when cultured explant on MS medium supplemented with $4 \mathrm{mg} / \mathrm{l}$ 2,4 D. without MnSO4. In rooting stage, full MS salt strength medium supplemented with $0.5 \mathrm{mg} / \mathrm{l}$ IBA led to the highest number of roots, Full MS salt strength medium supplemented with $2 \mathrm{mg} / \mathrm{l} \mathrm{IBA}$ gave the longest roots. Using peat moss as growing media produced the highest values of survival percentage, shoot length and number of leaves in acclimatization stage.
\end{abstract}

\section{INTRODUCTION}

Digitalis is typically a biennial plant but may be annual or perennial depending on the species. It is characterized by a thick, cylindrical, downy stem that reaches a height of up to $2 \mathrm{~m}$. Leaves form a thick rosette during the first year of growth. The leaves, which are woolly, veined, and covered with white hairs on the underside, have a very bitter taste. Flowers grow in the first or second year, depending on the species, and are tubular and bellshaped, growing to $8 \mathrm{~cm}$ in length. Many colors of flowers have been bred from digitalis, and they are rarely white. Digitalis is native to the British Isles, Western Europe, and parts of Africa, but is found today as an ornamental 
plant throughout the world. Related species that have found some use in traditional medicine include Digitalis lutea (straw foxglove), Digitalis grandiflora and Digitalis ambigua (yellow foxglove), and Digitalis ferriginea (rusty foxglove), (Morton, 1977, Warren, 2005 and USDA-NRCS, 2010).

Digitalis lanata contains a powerful cardiac stimulant that may be used by patients with heart conditions. Digoxin (Digitalin) is a drug that is extracted from Digitalis lanata. It is used to treat some heart conditions such as congestive heart failure. It has a tonic effect on heart disease enabling the heart to beat more slowly, powerfully, and regularly without requiring more oxygen. At the same time it stimulates the flow of urine, which lowers the volume of the blood and lessens the load on the heart. Digitalin was not discovered until the mid-19th century by two French scientists Homolle Ouevenne and Theodore Ouevenne. It wasn't until 1875 that Oscar Schmiedberg identified digoxin in the plant (Drgendorff, 1884). It was first isolated in the 1930s in Britain by Dr. Sydney Smith (Smith, 1931 and Trease, 1961). Back then it was used to treat ulcers in the lower abdomen, boils, headaches, abscesses, and paralysis, and externally healing wounds. Today it is still extracted from the plant because making it synthetically is quite expensive and difficult. However, it is becoming less frequently used due to the narrow therapeutic margin and high potential for severe side effects. Digoxin is being replaced by newer drugs including angiotensin-converting enzyme inhibitors, and the calcium channel blocking agents. As new pharmacotherapeutic agents arise, the use of digitalis preparations will continue to decline. There are also other commercial uses for Digitalis lanata other than heart conditions. For example, in South America the powdered leaves are used to relieve asthma, as sedatives, and as diuretics. In India it is used as an ointment that contains digitalis glycosides used to treat wounds and burns.

The aim of the present work is to investigate in vitro plant regeneration system of Digitalis lanata plant by using tissue culture technique.

\section{MATERIALS AND METHODS}

This work was carried out during the period from 2005 to 2009 at Biotechnology Department, tissue culture Department and Farm of Applied Research Center of Medicinal Plants (ARCMP) affiliated to the National Organization for Drug Control and Research (NODCAR). The aim of the present work is to investigate in vitro plant regeneration system of Digitalis lanata plant by using tissue culture technique addition using different treatments for increased the active constituent in plant .

\section{Plant material}

Plant shoot tip were taken from mature of Digitalis lanata, (3-4 months old) grown at green house of Applied Research Center of Medicinal Plants (ARCMP).

\section{Sterilization of plant material:}

The explants were sterilized by using distilled water, small amount of soap, $70 \%$ alcohol, $0.5 \% \mathrm{NaCl}, 0.2 \%$ mercuric chloride and tween 20 . 
The shoot tips were excised to the meristimatic dome with primordial leaves. The explants size was $5 \mathrm{~mm}$ in length, then explant was subsequently placed down vertically in the jars containing $25 \mathrm{ml}$ of (Murashige and Skoog, 1962). The $\mathrm{pH}$ of solution was adjusted to 5.7 using $1 \mathrm{~N} \mathrm{KOH}$, and the media were autoclaved at $121^{\circ} \mathrm{C}$ and 1.2 psi for 20 minutes.

The first experiment: starting stage

The aim of this experiment was to establish a sterile shoot in culture and obtaining successful proliferation of axillary buds for Digitalis lanata plant.

1. Effect of different concentrations of auxins (IBA and NAA) and cytokinetin (BA and Kin) on mean of survival percentage, number of shootlets (shootlet/explant), shootlets length $(\mathrm{cm})$ and leaf number (leaves/ explant) on starting stage of Digitalis lanata axillary buds explant.

The treatments are included respectively in the following treatments:-

\begin{tabular}{|c|c|}
\hline 1. MS free hormones & 10. $\mathrm{MS}+0.5 \mathrm{mg} / \mathrm{l} \mathrm{BA}$ \\
\hline 2. $M S+0.5 \mathrm{mg} / \mathrm{l} \mathrm{IBA}$ & 11. $\mathrm{MS}+1.0 \mathrm{mg} / \mathrm{l} \mathrm{BA}$ \\
\hline 3. MS +1.0 mg/l IBA & 12. $\mathrm{MS}+2.0 \mathrm{mg} / \mathrm{l} \mathrm{BA}$ \\
\hline 4. MS + $2.0 \mathrm{mg} / \mathrm{l} \mathrm{IBA}$ & 13. $\mathrm{MS}+3.0 \mathrm{mg} / \mathrm{l} \mathrm{BA}$ \\
\hline 5. $\mathrm{MS}+3.0 \mathrm{mg} / \mathrm{l} \mathrm{IBA}$ & 14. MS + $0.5 \mathrm{mg} / \mathrm{K} \mathrm{Kin}$ \\
\hline 6. MS + $0.5 \mathrm{mg} / \mathrm{l} \mathrm{NAA}$ & 15. MS +1.0 mg/l Kin \\
\hline 7. MS + $1.0 \mathrm{mg} / \mathrm{l} \mathrm{NAA}$ & 16. MS + $2.0 \mathrm{mg} / \mathrm{K} \mathrm{Kin}$ \\
\hline 8. $\mathrm{MS}+2.0 \mathrm{mg} / \mathrm{l} \mathrm{NAA}$ & 17. $\mathrm{MS}+3.0 \mathrm{mg} / \mathrm{K} \mathrm{Kin}$ \\
\hline 9. $\mathrm{MS}+3.0 \mathrm{mg} / \mathrm{l} \mathrm{NAA}$ & 18. $\mathrm{MS}+0.5 \mathrm{mg} / \mathrm{BA}$ \\
\hline
\end{tabular}

The following data were recorded after 6,12 and 18 weeks:

1. Survival percentage

2. Number of shoots/explant

3. Shoot length $(\mathrm{cm})$

4. Number of leaves/shoot.

2. Effect of combination of different concentrations of auxins (IBA and NAA) and cytokinenis (BA and Kin) on survivalpercentage,number of shoots/explant,shootlength $(\mathrm{cm})$,and number of leaves/shoot on Digitalis lanata plant.

The combination treatments are included respectively in the following treatments:-

\begin{tabular}{|c|c|}
\hline 1. MS free hormones & 6. MS + $0.5 \mathrm{mg} / \mathrm{l} \mathrm{Kin}+0.5 \mathrm{mg} / \mathrm{l} \mathrm{IBA}$ \\
\hline 2. $\mathrm{MS}+0.5 \mathrm{mg} / \mathrm{l} \mathrm{BA}+0.5 \mathrm{mg} / \mathrm{l} \mathrm{NAA}$ & 7. $\mathrm{MS}+1.0 \mathrm{mg} / \mathrm{l} \mathrm{Kin}+1.0 \mathrm{mg} / \mathrm{l} \mathrm{IBA}$ \\
\hline 3. $\mathrm{MS}+1.0 \mathrm{mg} / \mathrm{l} \mathrm{BA}+1.0 \mathrm{mg} / \mathrm{l} \mathrm{NAA}$ & 8. MS + $2.0 \mathrm{mg} / \mathrm{l} \mathrm{Kin} \mathrm{+2.0} \mathrm{mg/l} \mathrm{IBA}$ \\
\hline 4. $\mathrm{MS}+2.0 \mathrm{mg} / \mathrm{BA}+2.0 \mathrm{mg} / \mathrm{lNAA}$ & 9. MS + 3.0 mg/l Kin +3.0 mg/l IBA \\
\hline $5 . \mathrm{MS}+3.0 \mathrm{mg} / \mathrm{l} \mathrm{BA}+3.0 \mathrm{mg} / \mathrm{lNAA}$ & \\
\hline
\end{tabular}

The following data were recorded after 6 :

1. Survival percentage

2. Number of shoots/explant

3. Shoot length $(\mathrm{cm})$

4. Number of leaves/shoot. 
The scond experiment: Multiplication stage

1. Effect of different concentrations of auxin (IBA and NAA) and cytokinetin (BA and Kin) on mean of survival percentage, multiplication rate, number of (shootlet/explant), shootlets length (cm) , leaf number (leaves/ explant) and root percentage on multiplication stage on the plant.

The combination treatments are included respectively in the following treatments:-

\begin{tabular}{|c|c|}
\hline 1. MS free hormones & 10. $\mathrm{MS}+0.5 \mathrm{mg} / \mathrm{l} \mathrm{BA}+0.5 \mathrm{mg} / \mathrm{l} \mathrm{Kin}$ \\
\hline 2. MS + $0.5 \mathrm{mg} / \mathrm{l} \mathrm{NAA}+0.5 \mathrm{mg} / \mathrm{l} \mathrm{Kin}$ & 11. $\mathrm{MS}+1.0 \mathrm{mg} / \mathrm{l} \mathrm{BA}+1.0 \mathrm{mg} / \mathrm{l} \mathrm{Kin}$ \\
\hline 3. MS +1.0 mg/l NAA+1.0 mg/l Kin & 12. $\mathrm{MS}+2.0 \mathrm{mg} / \mathrm{l} \mathrm{BA}+2.0 \mathrm{mg} / \mathrm{l} \mathrm{Kin}$ \\
\hline 4. MS + $2.0 \mathrm{mg} / \mathrm{l} \mathrm{NAA}+2.0 \mathrm{mg} / \mathrm{l} \mathrm{Kin}$ & 13. $\mathrm{MS}+3.0 \mathrm{mg} / \mathrm{l} \mathrm{BA}+3.0 \mathrm{mg} / \mathrm{l} \mathrm{Kin}$ \\
\hline 5. MS + $3.0 \mathrm{mg} / \mathrm{l} \mathrm{NAA}+3.0 \mathrm{mg} / \mathrm{l} \mathrm{Kin}$ & 14. $\mathrm{MS}+0.5 \mathrm{mg} / \mathrm{l} \mathrm{IBA}+0.5 \mathrm{mg} / \mathrm{BA}$ \\
\hline 6. MS + $0.5 \mathrm{mg} / \mathrm{l} \mathrm{NAA}+0.5 \mathrm{mg} / \mathrm{l} \mathrm{BA}$ & 15. $\mathrm{MS}+1.0 \mathrm{mg} / \mathrm{l} \mathrm{IBA}+1.0 \mathrm{mg} / \mathrm{l} \mathrm{BA}$ \\
\hline 7. $\mathrm{MS}+1.0 \mathrm{mg} / \mathrm{l} \mathrm{NAA}+1.0 \mathrm{mg} / \mathrm{l} \mathrm{BA}$ & 16. $\mathrm{MS}+2.0 \mathrm{mg} / \mathrm{l} \mathrm{IBA}+2.0 \mathrm{mg} / \mathrm{l} \mathrm{BA}$ \\
\hline 8. MS + $2.0 \mathrm{mg} / \mathrm{l} \mathrm{NAA}+2.0 \mathrm{mg} / \mathrm{l} \mathrm{BA}$ & 17. $\mathrm{MS}+3.0 \mathrm{mg} / \mathrm{l} \mathrm{IBA}+3.0 \mathrm{mg} / \mathrm{l} \mathrm{BA}$ \\
\hline 9. $\mathrm{MS}+3.0 \mathrm{mg} / \mathrm{l} \mathrm{NAA}+3.0 \mathrm{mg} / \mathrm{lBA}$ & \\
\hline
\end{tabular}

The following data were recorded after 6,12 and 18 weeks:

1. Survival percentage.

2. Number of shoots/explant.

3. Shoot length $(\mathrm{cm})$.

4. Number of leaves/shoot.

5. Root percentage.

2. Effect of MS salt strength media supplemented with different concentrations of auxins (IBA and NAA) and cytokinetin (BA and Kin) on mean of survival percentage, multiplication rate, number of Shootlets (shootlet/explant), shootlets length $(\mathrm{cm})$, leaf number (leaves/ explant) and root percentage on multiplication stage on the plant.

This experiment was carried out to study the effect of MS salt strength at full strength, $3 / 4$ strength and $1 / 2$ strength supplemented with different concentrations of NAA, IBA, Kin and BA.

This experiment consisted of 13 treatments as follows:

\begin{tabular}{|c|c|}
\hline 1. $\mathrm{MS}$ & 8. ${ }^{3} / 4 \mathrm{MS}+0.4 \mathrm{mg} / \mathrm{l} \mathrm{IBA}+4.0 \mathrm{mg} / \mathrm{Kin}$ \\
\hline 2. $\mathrm{MS}+0.4 \mathrm{mg} / \mathrm{lNAA}+4.0 \mathrm{mg} / \mathrm{l} \mathrm{Kin}$ & 9. $3 / 4 \mathrm{MS}+0.4 \mathrm{mg} / \mathrm{l} \mathrm{IBA}+4.0 \mathrm{mg} / \mathrm{l} \mathrm{BA}$ \\
\hline 3. $\mathrm{MS}+0.4 \mathrm{mg} / \mathrm{l} \mathrm{NAA}+4.0 \mathrm{mg} / \mathrm{l} \mathrm{BA}$ & 10. $1 / 2 \mathrm{MS}+0.4 \mathrm{mg} / \mathrm{l} \mathrm{NAA}+4.0 \mathrm{mg} / \mathrm{l} \mathrm{Kin}$ \\
\hline $\mathrm{MS}+0.4 \mathrm{mg} / \mathrm{l} \mathrm{IBA}+4.0 \mathrm{mg} / \mathrm{l} \mathrm{Kin}$ & 11. ${ }^{1} / 2 \mathrm{MS}+0.4 \mathrm{mg} / \mathrm{l} \mathrm{NAA}+4.0 \mathrm{mg} / \mathrm{l} \mathrm{BA}$ \\
\hline 5. $\mathrm{MS}+0.4 \mathrm{mg} / \mathrm{l} \mathrm{IBA}+4.0 \mathrm{mg} / \mathrm{l} \mathrm{BA}$ & 12. $1 / 2 \mathrm{MS}+0.4 \mathrm{mg} / \mathrm{l} \mathrm{IBA}+4.0 \mathrm{mg} / \mathrm{l} \mathrm{Kin}$ \\
\hline 6. $3 / 4 \mathrm{MS}+0.4 \mathrm{mg} / \mathrm{l} \mathrm{NAA}+4.0 \mathrm{mg} / \mathrm{Kin}$ & 13. $1 / 2 \mathrm{MS}+0.4 \mathrm{mg} / \mathrm{l} \mathrm{IBA}+4.0 \mathrm{mg} / \mathrm{lBA}$ \\
\hline 7. $3 / 4 \mathrm{MS}+0.4 \mathrm{mg} / \mathrm{l} \mathrm{NAA}+4.0 \mathrm{mg} / \mathrm{lBA}$ & \\
\hline
\end{tabular}

The treatment consisted of 4 replicates for three subcultures (each one every 6 weeks).

The following data were recorded

1. Survival percentage.

2. Number of shoots/explant

3. Shoot length $(\mathrm{cm})$

4. Number of leaves/shoot.

5. Root percentage. 
The third experiment: Callus induction stage

1. Effect of different concentrations of 2,4-D on mean of callus percentage, callus fresh weight and callus dry weight on callus induction stage on the plant.

The following 8 treatments were used:

\begin{tabular}{|c|c|}
\hline 1. $\mathrm{MS}+1.0 \mathrm{mg} / \mathrm{/2} 2,4-\mathrm{D}$ & 5. MS + $1.0 \mathrm{mg} / \mathrm{l} 2,4-\mathrm{D}+1.0 \mathrm{mg} / \mathrm{l} \mathrm{MnSO} 4$ \\
\hline 2. $\mathrm{MS}+1.0 \mathrm{mg} / \mathrm{l} 2,4-\mathrm{D}$ & 6. MS + $1.0 \mathrm{mg} / \mathrm{l} 2,4-\mathrm{D}+1.0 \mathrm{mg} / \mathrm{l} \mathrm{MnSO}{ }_{4}$ \\
\hline 3. MS + $2.0 \mathrm{mg} / \mathrm{l} 2,4-\mathrm{D}$ & 7. $\mathrm{MS}+2.0 \mathrm{mg} / \mathrm{l} 2,4-\mathrm{D}+1.0 \mathrm{mg} / \mathrm{l} \mathrm{MnSO}_{4}$ \\
\hline 4. $M S+3.0 \mathrm{mg} / \mathrm{l} 2,4-\mathrm{D}$ & 8. MS+3.0 mg/l 2,4-D+1.0 mg// $\mathrm{MnSO}_{4}$ \\
\hline
\end{tabular}

Each treatment contains 4 replicates, the data recorded after 45 days. The following data were recorded:

1. Callus percentage.

2. Fresh weight of callus.

3. Dry weight of callus.

The fourth experiment: Rooting stage

1. Effect of MS media salt strength supplemented with different concentrations of auxins (IBA and NAA) and cytokinetin (BA and Kin) on mean of rooting percentage, number of roots (roots/shootlet) and root length $(\mathrm{cm})$ on rooting stage on the plant.

This experiment consisted of 13 treatments as follows:

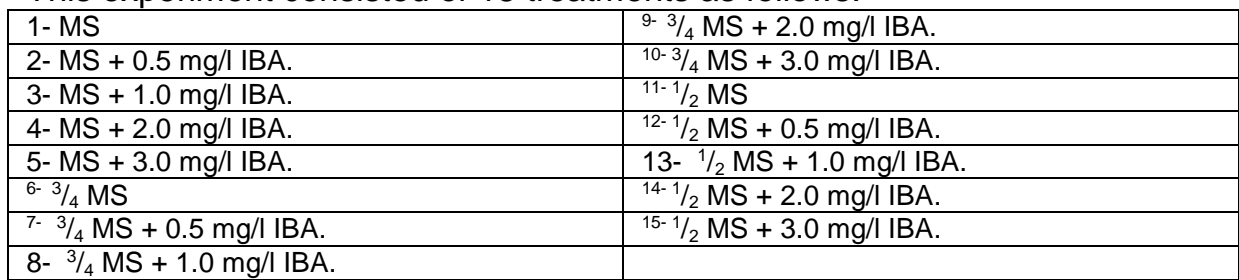

The fifth experiment: Acclimatization stage

1. Effect of different media growing on acclimatization stage on mean of survival percentage, shoot length $(\mathrm{cm})$ and number of leaves (leaves/plantlet) on the plant.

This experiment was conducted in the greenhouse to evaluate the effect of growing media on the survival percentage of two varieties of Digitalis lanata plantlets during the acclimatization stage. The plantlets (4-6 leaves produced in vitro) were individually transplanted into $8 \mathrm{~cm}$ plastic pots filled with

1. Peat moss : Sand $(1: 0)$

2. Peat moss : Sand $(1: 1)$

3. Peat moss : Sand $(1: 2)$

4. Peat moss : Sand $(1: 3)$

5. Peat moss : Sand $(3: 1)$

Each treatment included 10 pots (10 replicates). All plantlets were washed thoroughly with tap water to remove the remains of agar from the root system. After planting, the plantlets were irrigated with water containing antibiotic (Streptomycin $0.1 \%$ ) and fungicide (Topsin $0.1 \%$ ). 
The plantlets were hole in the greenhouse under high relative humidity using white polyethylene bags for one week to maintain humidity over plantlets. One week later, the cover of polyethylene bags were repeatedly perforated with one hole for four times at one week intervals.

After two weeks the polyethylene bags were totally removed before transplanting outdoors. At the end of acclimatization period (after four weeks) plantlet ex vitro were subjected to the following measurements:

1. Survival percentage;

2. Shoot length $(\mathrm{cm})$

3. Leaves number per plantlet.

\section{RESULTS AND DISCUSSION}

\section{Starting stage}

1. Effect of different concentrations of auxins (IBA and NAA) and cytokinenis (BA and Kin) on mean of survival percentage, multiplication rate, number of Shootlets (shootlet/explant), shootlets length $(\mathrm{cm})$, leaf number (leaves/ explant) and root percentage on Digitalis lanata plant.

Data presented in Table (1) showed that, MS medium supplemented with $3 \mathrm{mg} / \mathrm{l}$ IBA giving the best results of survival percentage (91.7\%), but the lowest result giving when cultured explant on MS medium free hormones.

The highest number of shoots (1.9) obtained by explanted cultured on MS medium supplemented with $2 \mathrm{mg} / \mathrm{l} \mathrm{BA}$, while the tallest shoots (3.5 $\mathrm{cm}$ ) were obtained by cultured explant on MS medium supplemented with 2 $\mathrm{mg} / \mathrm{l} \mathrm{Kin}$, but the shortest shoots $(1.9 \mathrm{~cm})$ were obtained when cultured explants on MS medium free hormones.

Table 1: Effect of different concentration of auxin (IBA and NAA) and cytokinenis (BA and Kin) on mean of survival percentage, number of shoots, shoot length $(\mathrm{cm})$ and leaf number (leaves/explant) on starting stage of Digitalis lanata plant.

\begin{tabular}{|c|c|c|c|c|c|}
\hline \multicolumn{2}{|c|}{ Treatments } & $\begin{array}{c}\text { Survival } \\
\text { percentage }\end{array}$ & $\begin{array}{c}\text { Number of shoots } \\
\text { (shoots /explant) }\end{array}$ & $\begin{array}{c}\text { Shoot length } \\
\text { (cm) }\end{array}$ & $\begin{array}{c}\text { Leaf number } \\
\text { (leaves/explant) }\end{array}$ \\
\hline Free hormones & 0.0 & 62.0 & 1.0 & 1.9 & 5.0 \\
\hline \multirow{4}{*}{ IBA (mg/l) } & 0.5 & 62.0 & 1.0 & 2.9 & 9.0 \\
\cline { 2 - 6 } & 1.0 & 69.0 & 1.2 & 2.7 & 11.0 \\
\cline { 2 - 6 } & 2.0 & 84.3 & 1.6 & 2.8 & 13.0 \\
\cline { 2 - 6 } & 3.0 & 91.7 & 1.0 & 2.7 & 12.3 \\
\hline \multirow{4}{*}{ NAA (mg/l) } & 0.5 & 82.0 & 1.0 & 2.2 & 8.4 \\
\cline { 2 - 6 } & 1.0 & 85.0 & 1.1 & 2.6 & 9.8 \\
\cline { 2 - 6 } & 2.0 & 85.0 & 1.6 & 3.0 & 12.3 \\
\cline { 2 - 6 } & 3.0 & 88.0 & 1.0 & 2.9 & 11.0 \\
\hline \multirow{4}{*}{ Kin (mg/l) } & 0.5 & 72.0 & 1.0 & 2.0 & 5.0 \\
\cline { 2 - 6 } & 1.0 & 75.0 & 1.5 & 2.0 & 4.8 \\
\cline { 2 - 6 } & 2.0 & 80.0 & 1.8 & 3.5 & 3.7 \\
\cline { 2 - 6 } & 3.0 & 80.0 & 1.8 & 2.3 & 2.2 \\
\hline \multirow{3}{*}{ BA (mg/l) } & 0.5 & 90.0 & 1.0 & 2.5 & 5.0 \\
\cline { 2 - 6 } & 1.0 & 87.0 & 1.6 & 3.0 & 4.5 \\
\cline { 2 - 6 } & 2.0 & 87.0 & 1.9 & 1.8 & 2.0 \\
\cline { 2 - 6 } & 3.0 & 83.0 & $\mathrm{~B}$ & 3.0 & \\
\hline
\end{tabular}

L.S.D.0.05

$A=0.95 \quad B=0.58 \quad A B=1.60$ 
Also, Table (1) cleared that, the MS medium supplemented with $3 \mathrm{mg} / \mathrm{l}$ Kin giving the lowest leaf number (2.2) but was 13 leaves per shoot when cultured explant on MS medium supplemented with $2 \mathrm{mg} / \mathrm{I} \mathrm{IBA}$.

2. These results were in accordance with the finding (Varadarajan et al., 2006) who reported that the highest number of shoots was observed in MS medium supplemented with 2-3 mg benzyladenine/litre when cultured nodal explant of Boerhaavia diffusa. In this connection (Koilpillai and Wilson ,2010) recorded that the shoot length was also measured individually and maximum of $4.1 \mathrm{~cm}$ was recorded on MS media fortified with kinetin 9.28 micro M/l on Graptophyllum pictum.

3. Effect of combination of different concentrations of auxins (IBA and NAA) and cytokinenis (BA and Kin) on Digitalis lanata plant

The result illustrated in Table (2) appeared that, MS medium supplemented with $2 \mathrm{mg} / \mathrm{l} \mathrm{Kin}+2 \mathrm{mg} / \mathrm{l} \mathrm{IBA}$ giving the best result of survival percentage $(91 \%)$, but MS medium free hormones giving the lowest result of survival percentage $(62 \%)$. The longest shoots $(2.4 \mathrm{~cm})$ were obtained when cultured explant on MS medium supplemented with $2 \mathrm{mg} / \mathrm{l} \mathrm{Kin}+2 \mathrm{mg} / \mathrm{lBA}$ or $3 \mathrm{mg} / \mathrm{l}$ $\mathrm{Kin}+3 \mathrm{mg} / \mathrm{l}$ IBA, but the shortest shoots $(1.9 \mathrm{~cm})$ were obtained when cultured explant on MS medium free hormones.

Concerning the effect of leaf number, the results revealed that, MS medium free hormones giving the highest leaf number (5 leaves per explant), while MS medium supplemented with $0.5 \mathrm{mg} / \mathrm{K} \mathrm{Kin}+0.5 \mathrm{mg} / \mathrm{l}$ IBA give the lowest leaf number (3 leaves per explant).

This results agree with finding by Monika et al., (2010) who showed that MS supplemented with Kin+lBA (0.2 mg/l each) or Kin+lBA $(0.5 \mathrm{mg} / \mathrm{l}$ each) favoured best response in terms of leaf length and rooting, respectively, when cultured nodal segments of Tylophora asthamatica on MS half strength and MS full strength media containing different concentrations and combinations of auxins (IAA and IBA) and cytokinins (Kinetin and BAP).

Table 2: Effect of different concentration of auxin (IBA and NAA) and cytokinenis (BA and Kin) on mean of survival percentage, number of shoots, shoot length $(\mathrm{cm})$ and leaf number (leaves/explant) on starting stage of Digitalis lanata plant.

\begin{tabular}{|c|c|c|c|c|c|}
\hline \multicolumn{2}{|c|}{ Treatments } & $\begin{array}{c}\text { Survival } \\
\text { percentage }\end{array}$ & $\begin{array}{c}\text { Number of } \\
\text { shoots } \\
\text { (shoots /explant) }\end{array}$ & $\begin{array}{c}\text { Shoot } \\
\text { length (cm) }\end{array}$ & $\begin{array}{c}\text { Leaf number } \\
\text { (leaves/explant) }\end{array}$ \\
\hline Free hormones & 0.0 & 62.0 & 1.0 & 1.9 & 5.0 \\
\hline \multirow{4}{*}{ BA/NAA (mg/I) } & $0.5 / 0.5$ & 83.0 & 1.0 & 2.2 & 4.0 \\
\cline { 2 - 6 } & $1.0 / 1.0$ & 90.0 & 1.0 & 2.9 & 4.3 \\
\cline { 2 - 6 } & $2.0 / 2.0$ & 90.0 & 1.8 & 2.7 & 4.9 \\
\cline { 2 - 6 } & $3.0 / 3.0$ & 75.0 & 2.1 & 2.0 & 4.2 \\
\hline \multirow{3}{*}{ Kin/IBA (mg/l) } & $0.5 / 0.5$ & 83.0 & 1.0 & 2.0 & 3.0 \\
\cline { 2 - 6 } & $1.0 / 1.0$ & 89.0 & 1.9 & 2.5 & 3.1 \\
\cline { 2 - 6 } & $2.0 / 2.0$ & 91.0 & 2.4 & 3.3 & 4.0 \\
\cline { 2 - 6 } & $3.0 / 3.0$ & 85.0 & 2.0 & 3.3 & 4.2 \\
\hline \multirow{2}{*}{ L.S.D. 0.05} & $\mathbf{A = 0 . 9 0}$ & $\mathbf{B = 0 . 3 7}$ & $\mathbf{A B}=\mathbf{1 . 2 8}$ & & \\
\hline
\end{tabular}




\section{Multiplication stage}

1. Effect of different concentrations of auxins (IBA and NAA) and cytokinetin (BA and Kin) on mean of survival percentage, multiplication rate, number of (shootlet/explant), shootlets length (cm) , leaf number (leaves/ explant) and root percentage on multiplication stage of Digitalis lanata plant.

As shown in Table (3) it is evident that, MS medium supplemented with $0.3 \mathrm{mg} / \mathrm{l} \mathrm{NAA}+0.5 \mathrm{mg} / \mathrm{l} \mathrm{BA}$ give the highest survival percentage $(91.3 \%)$, while the lowest survival percentage (81\%) was obtained when cultured explant on MS medium supplemented with $0.5 \mathrm{mg} / \mathrm{l} \mathrm{IBA}+0.5 \mathrm{mg} / \mathrm{l} \mathrm{Kin}$.

Table 3: Effect of different concentration of auxin (IBA and NAA) and cytokinenis (BA and Kin) on mean of survival percentage, number of shoots, shoot length $(\mathrm{cm})$ and leaf number (leaves/explant) and root percentage on multiplication stage of Digitalis lanata plant.

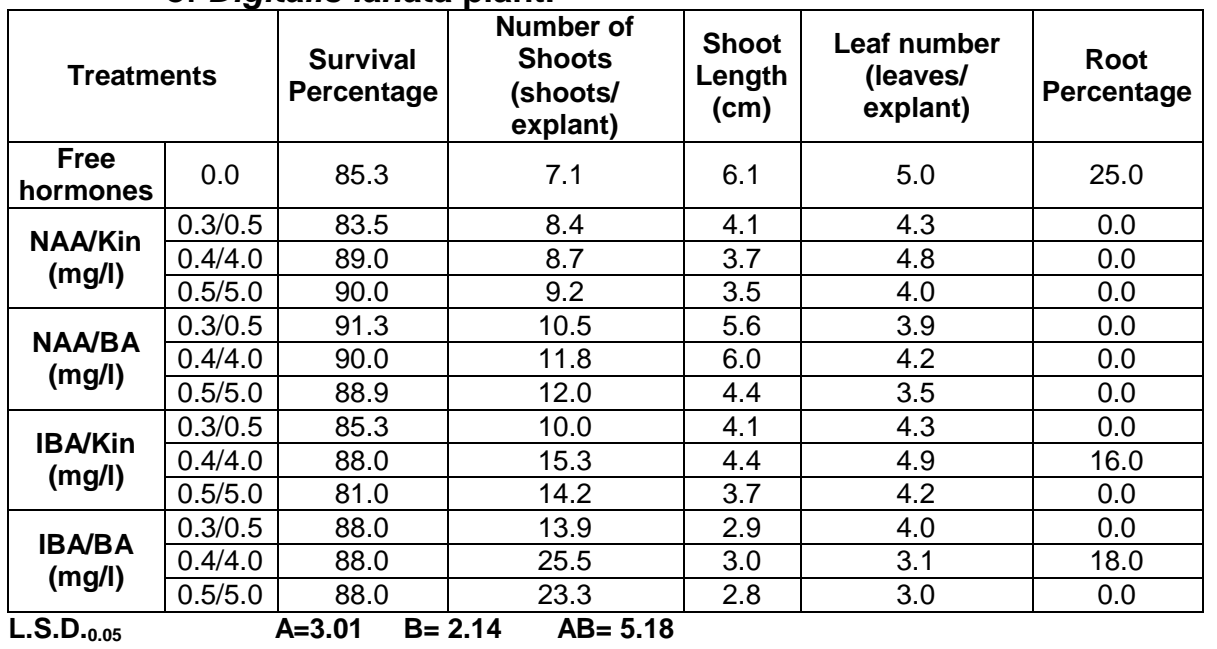

Also the data in table (3) showed that, MS medium free hormones giving the lowest number of shoots was 7.1 , the tallest shoots was $6.1 \mathrm{~cm}$, the highest amount of leaf number was 5 and root percentage was 25 .

On the other hand, the highest amount of number of shoots was 25.5 obtained when cultured explant on MS medium supplemented with $0.4 \mathrm{mg} / \mathrm{l}$ IBA + $4.0 \mathrm{mg} / \mathrm{l} \mathrm{BA}$, while MS medium supplemented with $0.5 \mathrm{mg} / \mathrm{l} \mathrm{IBA}+5.0$ $\mathrm{mg} / \mathrm{l} \mathrm{BA}$ giving the shortest shoots was $2.8 \mathrm{~cm}$ and the lowest number of leaves was 3 leaves/ explant .

These results were is agree with the finding by Monika et al., (2010) $\mathrm{BAP}+\mathrm{IBA}(1.0 \mathrm{mg} / \mathrm{l}$ each) favoured best response in terms of leaf number on Tylophora asthamatica plant. 
2. Effect of MS salt strength media supplemented with different concentrations of auxins (IBA and NAA) and cytokinetin (BA and Kin) on mean of survival percentage, multiplication rate, number of Shootlets (shootlet/explant), shootlets length (cm), leaf number (leaves/ explant) and root percentage on multiplication stage of Digitalis lanataplant.

Concerning the effect of full MS salt strength medium supplemented with different concentrations of auxin and cytokinetin on multiplication stage are presented in Table (4). The data showed that, full MS medium salt strength medium gives the best result of survival percentage, number of shoots, shoot length and leaf number compared with $3 / 4$ and 1/2 MS salt strength medium, while $3 / 4 \mathrm{MS}$ salt strength medium gives the best result of root percentage.

Table 4. Effect of MS salt strength media supplemented with different concentrations of auxin (IBA and NAA) and cytokinetin (BA and $\mathrm{Kin}$ ) on mean of survival percentage, multiplication rate, number of Shootlets (shootlet/explant), shootlets length $(\mathrm{cm})$, leaf number (leaves/ explant) and root percentage on multiplication stage of Digitalis lanata plant.

\begin{tabular}{|c|c|c|c|c|c|c|}
\hline & Treatments & $\begin{array}{c}\text { Survi- } \\
\text { val } \\
\text { Perce- } \\
\text { ntage }\end{array}$ & $\begin{array}{l}\text { Number } \\
\text { of shoots } \\
\text { (shoots/ } \\
\text { explant) }\end{array}$ & $\begin{array}{l}\text { Shoot } \\
\text { length } \\
\text { (cm) }\end{array}$ & $\begin{array}{c}\text { Leaf } \\
\text { number } \\
\text { (leaves/ } \\
\text { explant) }\end{array}$ & $\begin{array}{c}\text { Root } \\
\text { Perce- } \\
\text { ntage }\end{array}$ \\
\hline \multirow{4}{*}{$\begin{array}{l}\text { MS full } \\
\text { strength }\end{array}$} & $0.4 \mathrm{mg} / \mathrm{l} \mathrm{NAA}+4.0 \mathrm{mg} / \mathrm{l} \mathrm{Kin}$ & 91.0 & 8.7 & 3.9 & 5.0 & 0.0 \\
\hline & $0.4 \mathrm{mg} / \mathrm{l} \mathrm{NAA}+4.0 \mathrm{mg} / \mathrm{l} \mathrm{BA}$ & 88.5 & 12.2 & 6.0 & 4.8 & 0.0 \\
\hline & $0.4 \mathrm{mg} / \mathrm{l} \mathrm{IBA}+4.0 \mathrm{mg} / \mathrm{l} \mathrm{Kin}$ & 89.0 & 15.5 & 4.4 & 4.9 & 17.0 \\
\hline & $0.4 \mathrm{mg} / \mathrm{l} \mathrm{IBA}+4.0 \mathrm{mg} / \mathrm{l} \mathrm{BA}$ & 93.0 & 26.5 & 3.0 & 4.0 & 18.0 \\
\hline \multirow{4}{*}{$\begin{array}{l}3 / 4 \mathrm{MS} \\
\text { strength }\end{array}$} & $0.4 \mathrm{mg} / \mathrm{l} \mathrm{NAA}+4.0 \mathrm{mg} / \mathrm{l} \mathrm{Kin}$ & 83.3 & 7.1 & 3.5 & 4.3 & 0.0 \\
\hline & $0.4 \mathrm{mg} / \mathrm{l} \mathrm{NAA}+4.0 \mathrm{mg} / \mathrm{l} \mathrm{BA}$ & 81.0 & 10.5 & 5.5 & 4.2 & 0.0 \\
\hline & $0.4 \mathrm{mg} / \mathrm{l} \mathrm{IBA}+4.0 \mathrm{mg} / \mathrm{l} \mathrm{Kin}$ & 83.0 & 10.0 & 4.1 & 4.3 & 25.0 \\
\hline & $0.4 \mathrm{mg} / \mathrm{l} \mathrm{IBA}+4.0 \mathrm{mg} / \mathrm{l} \mathrm{BA}$ & 88.0 & 18.3 & 2.9 & 3.2 & 25.0 \\
\hline \multirow{4}{*}{$\begin{array}{l}1 / 2 \mathrm{MS} \\
\text { strength }\end{array}$} & $0.4 \mathrm{mg} / \mathrm{l} \mathrm{NAA}+4.0 \mathrm{mg} / \mathrm{l} \mathrm{Kin}$ & 88.3 & 7.0 & 3.3 & 4.0 & 0.0 \\
\hline & $0.4 \mathrm{mg} / \mathrm{l} \mathrm{NAA}+4.0 \mathrm{mg} / \mathrm{l} \mathrm{BA}$ & 79.0 & 9.2 & 4.3 & 3.5 & 0.0 \\
\hline & $0.4 \mathrm{mg} / \mathrm{l} \mathrm{IBA}+4.0 \mathrm{mg} / \mathrm{l} \mathrm{Kin}$ & 83.0 & 8.8 & 3.7 & 4.2 & 0.0 \\
\hline & $0.4 \mathrm{mg} / \mathrm{l} \mathrm{IBA}+4.0 \mathrm{mg} / \mathrm{l} \mathrm{BA}$ & 87.0 & 14.4 & 2.1 & 3.0 & 0.0 \\
\hline
\end{tabular}

Full MS salt strength medium supplemented with $0.4 \mathrm{mg} / \mathrm{l} \mathrm{NAA}+4.0$ $\mathrm{mg} / \mathrm{l}$ Kin gives the highest survival percentage $(91 \%)$ and leaf number $(5$ leaves per explant), meanwhile full MS salt strength medium supplemented with $0.4 \mathrm{mg} / \mathrm{l}$ IBA $+4.0 \mathrm{mg} / \mathrm{l} \mathrm{BA}$ gives the longest shoots and the highest number of shoots ( $6 \mathrm{~cm}$ and 26.5 shoot/ explant, respectively).

$3 / 4 \mathrm{MS}$ salt strength medium supplemented with $0.4 \mathrm{mg} / \mathrm{l}$ IBA $+4.0 \mathrm{mg} / \mathrm{l}$ Kin or $0.4 \mathrm{mg} / \mathrm{l}$ IBA $+4.0 \mathrm{mg} / \mathrm{l} \mathrm{BA}$ gives the highest root percentage $(25 \%)$.

$1 / 2 \mathrm{MS}$ salt strength medium supplemented with $0.4 \mathrm{mg} / \mathrm{l} \mathrm{NAA}+4.0$ $\mathrm{mg} / \mathrm{l} \mathrm{Kin} \mathrm{gives} \mathrm{the} \mathrm{lowest} \mathrm{number} \mathrm{of} \mathrm{shoots} \mathrm{(7} \mathrm{shoots} \mathrm{per} \mathrm{explant),} \mathrm{while} \mathrm{1/2}$ MS salt strength medium supplemented with $0.4 \mathrm{mg} / \mathrm{l} \mathrm{NAA}+4.0 \mathrm{mg} / \mathrm{l} \mathrm{BA}$ gives the lowest survival percentage (79\%). But $1 / 2 \mathrm{MS}$ salt strength medium supplemented with $0.4 \mathrm{mg} / \mathrm{l} \mathrm{IBA}+4.0 \mathrm{mg} / \mathrm{l} \mathrm{BA}$ gives the shortest shoots and lowest leaf number $(2.1 \mathrm{~cm}$ and 3 leaves per explant, respectively). 
These results were in accordance with the finding of Sawsan (2002) who showed that on Solidago altissima var. (Toto), the greatest number of shoots was produced on MS full strength. In this connection, Sakr et al. (1999) reported that MS full medium strength was more effective in increasing the number of shoots/explant than other medium strength.

\section{Callus induction stage}

1. Effect of different concentrations of 2,4-D on mean of callus percentage, callus fresh weight and callus dry weight and callus induction stage of Digitalis lanata plant.

Data existed in Table (5) cleared that, MS medium supplemented with 2 and $3 \mathrm{mg} / \mathrm{l}$ 2,4 D. with or without $\mathrm{MnSO}_{4}$ gives $100 \%$ survival percentage, while MS medium supplemented with $4 \mathrm{mg} / \mathrm{l}$ 2,4 D. with or without $\mathrm{MnSO}_{4}$ gives the lowest percentage survival $(83 \%)$ and callus fresh weight.

The highest callus dry weight $(0.37 \mathrm{gm})$ was obtained when cultured explant on MS medium supplemented with $4 \mathrm{mg} / \mathrm{l}$ 2,4 D without $\mathrm{MnSO}_{4}$, but MS medium supplemented with $4 \mathrm{mg} / \mathrm{l} 2,4 \mathrm{D}$ with $1 \mathrm{mg} / \mathrm{l} \mathrm{MnSO}_{4}$ gives the lowest callus dry weight $(0.17 \mathrm{gm})$.

The same trend was observed by (Kakad et al., 2009 who reported that on Rauvolfia serpentine quality callus (embryogenic, greenish-white and friable) was observed in MS + 2,4-D at $3 \mathrm{mg} / \mathrm{litre}$ and relatively hard and compact callus was observed in lower doses of 2,4-D and white and soft callus was observed in higher 2,4-D rates, which may due to the increased moisture content of callus in higher levels of 2,4-D. The maximum growth of callus was observed on MS + 2,4-D at $4 \mathrm{mg} /$ litre (90.680\%) after 30 days of subculture over the initial fresh weight, followed by MS +2,4-D at $3 \mathrm{mg} /$ litre $(89.696 \%)$ and the minimum on MS + 2,4-D at $1.0 \mathrm{mg} / \mathrm{litre}(22.734 \%)$ on a fresh weight basis

Table (5): Effect of different concentrations of 2,4-D on mean of callus percentage, callus fresh weight and callus dry weight on callus induction stage on Digitalis lanata.

\begin{tabular}{|c|c|c|c|c|c|c|c|c|}
\hline \multirow{2}{*}{ Treatments } & \multicolumn{8}{|c|}{$\mathrm{MnSO}_{4}$} \\
\hline & \multicolumn{4}{|c|}{0} & \multicolumn{4}{|c|}{1} \\
\hline 2,4 D. $\mathrm{mg} / \mathrm{l}$ & 1 & 2 & 3 & 4 & 1 & 2 & 3 & 4 \\
\hline Callus percentage & 85.0 & 100.0 & 100.0 & 83.0 & 90.0 & 100.0 & 100.0 & 83.0 \\
\hline Callus fresh weight (gm) & 2.9 & 3.5 & 2.9 & 2.0 & 2.4 & 3.1 & 3.0 & 2.0 \\
\hline Callus dry weight (gm) & 0.29 & 0.37 & 0.21 & 0.20 & 0.28 & 0.33 & 0.30 & 0.17 \\
\hline
\end{tabular}

$\begin{array}{llll}\text { L.S.D.0.05 } & \mathrm{A}=1.40 & \mathrm{~B}=0.72 & \mathrm{AB}=2.15\end{array}$

\section{Rooting stage}

1. Effect of MS media salt strength supplemented with different concentrations of auxins (IBA and NAA) and cytokinetin (BA and Kin) on mean of rooting percentage, number of roots (roots/shootlet) and root length $(\mathrm{cm})$ on rooting stage of Digitalis lanata plant.

The results illustrated in Table (6) appeared that, full MS salt strength medium at all treatments giving the best result of rooting percentage, number of roots and root length compared with $1 / 2 \mathrm{MS}$ salt strength medium giving the lowest results. 
Also the data in Table (6) showed that, full MS salt strength medium supplemented with $0.5 \mathrm{mg} / \mathrm{I}$ IBA giving the highest number of roots was 3.2 root per shootlet, while full MS salt strength medium supplemented with 2 $\mathrm{mg} / \mathrm{l}$ IBA giving the longest roots was $(3 \mathrm{~cm})$.

In the same trend, Mukundan et al.,2004) showed that roots developed in all the microshoots of Centella asiatica on MS medium containing 4.9 micro M IBA. In these connection, Mahender et al., (2008) showed that the elongated shoots of Scoparia dulcis L. were separated and transferred onto MS medium supplemented with indole-3-butyric acid (IBA, 4.9 micro M).

Table 6: Effect of MS media salt strength supplemented with differentconcentrations of auxin (IBA and NAA) and cytokinetin (BA and Kin)on mean of rooting percentage, number of roots (roots/shootlet) and root length $(\mathrm{cm})$ on rooting stage on Digitalis lanata plant.

\begin{tabular}{|c|c|c|c|c|}
\hline \multicolumn{2}{|c|}{ Treatments } & $\begin{array}{c}\text { Rooting } \\
\text { percentage }\end{array}$ & $\begin{array}{c}\text { Number of } \\
\text { roots }\end{array}$ & Root length (cm) \\
\hline \multicolumn{2}{|c|}{ Free hormones } & 93.0 & 1.6 & 2.0 \\
\hline \multirow{4}{*}{$\begin{array}{l}\text { MS full strength / } \\
\text { IBA(mg/l) }\end{array}$} & 0.5 & 100.0 & 3.2 & 2.1 \\
\hline & 1.0 & 100.0 & 3.9 & 2.1 \\
\hline & 2.0 & 100.0 & 2.4 & 3.0 \\
\hline & 3.0 & 100.0 & 2.3 & 2.8 \\
\hline \multicolumn{2}{|c|}{ 3/4 MS free hormones } & 86.0 & 1.3 & 2.0 \\
\hline \multirow{4}{*}{$\begin{array}{c}\text { 3/4 MS full strength } \\
\text { / IBA(mg/l) }\end{array}$} & 0.5 & 89.0 & 2.8 & 2.0 \\
\hline & 1.0 & 85.0 & 2.4 & 2.0 \\
\hline & 2.0 & 74.0 & 2.3 & 2.3 \\
\hline & 3.0 & 86.0 & 2.0 & 2.5 \\
\hline \multicolumn{2}{|c|}{ 1/2 MS free hormones } & 80.0 & 1.2 & 1.8 \\
\hline \multirow{4}{*}{$\begin{array}{c}\text { 1/2 MS full strength } \\
/ \text { IBA(mg/l) }\end{array}$} & 0.5 & 85.0 & 2.7 & 1.9 \\
\hline & 1.0 & 82.0 & 2.0 & 1.8 \\
\hline & 2.0 & 72.0 & 1.6 & 2.0 \\
\hline & 3.0 & 86.0 & 1.2 & 2.2 \\
\hline
\end{tabular}

\section{Acclimatization stage}

1. Effect of different growing media on acclimatization stage on mean of survival percentage, shoot length $(\mathrm{cm})$ and number of leaves (leaves/plantlet) of Digitalis lanataplant.

Data in Table (7) showed that, the different treatments caused significant effect on the survival percentage, shoot length and number of leaves. Peat moss : sand (1:0) growing media produced the highest values of survival percentage, shoot length and number of leaves $(100 \%, 21 \mathrm{~cm}$ and 19.2 leaves per plantlet, respectively), but peat moss : sand (1:3) growing media gives the lowest values of the survival percentage, shoot length and number of leaves (45\%, $8.6 \mathrm{~cm}$ and 13.9 leaves per plantlet, respectively).

Similar results were reported by Sumit et al. (2005) when transferred rooted shoots of Arnebia eucroma to a mixture of sterile soil, sand and peat (1:1:1 by volume) showed $72 \%$ survival ex vitro. In the connection, [17] ElKazzaz et al. (1997) showed, acclimatization of Monus alba in a mixture of 
peat moss and sand $(1: 1 \mathrm{v} / \mathrm{v})$ gave the highest transplant survival percentages (100\%) after 40 days.

Table (7): Effect of different growing media on mean of survival percentage, shoot length $(\mathrm{cm})$ and number of leaves (leaves/plantlet) of Digitalis lanata plant during the acclimatization stage

\begin{tabular}{|c|c|c|c|}
\hline Treatments & $\begin{array}{c}\text { Survival } \\
\text { percentage }\end{array}$ & \begin{tabular}{|c|}
$\begin{array}{c}\text { Shoot length } \\
(\mathrm{cm})\end{array}$ \\
\end{tabular} & $\begin{array}{c}\text { Number of leaves } \\
\text { (leaves/ plantlet) }\end{array}$ \\
\hline Peat moss : Sand $(1: 0)$ & 100.0 & 21.0 & 19.2 \\
\hline Peat moss : Sand $(1: 1)$ & 65.0 & 15.0 & 16.5 \\
\hline Peat moss : Sand $(1: 2)$ & 55.0 & 8.8 & 15.5 \\
\hline Peat moss : Sand (1:3) & 45.0 & 8.6 & 13.9 \\
\hline Peat moss : Sand $(3: 1)$ & 75.0 & 11.0 & 17.7 \\
\hline
\end{tabular}

\section{REFERENCES}

Digitalis purpurea L. USDA, NRCS. (2010). The PLANTS Database (http://plants.usda.gov,\%20march\%202010/). National Plant Data Center, Baton Rouge, LA 70874-4490 USA.

Dragendorff, G. (1884). Plant Analysis Qualitative \& Quantitative. London: Bailliere, Tindall and Cox. p. 142.

El-Kazzaz, A., Fahmy, G., Bahr, M., Hanafy, M. and Moemen, S. (1997). Propagation of mulberry (Monus alba L.) via tissue culture. Bulletin of the National Research Center, Cairo. 22:2, 175-188.

Kakad, I. A.; Vaidya, E. R. ; Smita S. ; Deshmukh, A. G. and Dudhare,M. S. (2009). In vitro callus induction and regeneration studies in Sarpagandba. Annals of Plant Physiology. 23: 1, 28-30.

Koilpillai, Y. J. and Wilson, S. (2010). In vitro propagation of Graptophyllum pictum L. (Acanthaceae) - a medicinal plant. Journal of Pharmacy Research. 3: 9, 2201-2202.

Mahender A.; Kokkirala, V. R.; Kota, S. R.; Pavan U. and Sadanandam A. (2008). Efficient in-vitro regeneration from mature leaf explants of Scoparia dulcis L., an ethnomedicinal plant. Journal of Herbs, Spices \& Medicinal Plants.14: 3-4, 200-207.

Monika, Y.; Padmanabh, D.; Pallavi, S. and Singh, V. K. (2010). In vitro culture protocol of Tylophora asthmatica an anti-asthmatic medicinal herb. Indian Journal of Plant Physiology.15: 3, 297-301.

Morton J.F. (1977). Major Medicinal Plants. Springfield, I.L: Charles C. Thomas.

Mukundan, U.; Shrotri , M . and Gavhane , R.(2004). In vitro plant regeneration of Centella asiatica and determination of Asiaticoside using HPTLC. Journal of Tropical Medicinal Plants. 5: 1, 89-94.

Murashige, T. and Skoog, F. (1962). A revised medium for rapid growth and bioassays with tobacco tissue culture. Plant Physiol., 15: 473-497. 
Sakr, S. S.; El-Khateeb, M. A. and Abdel Kareim, A. H. (1999). Micropropagation of Magnolia grandiflora L. through tissue culture technique. Bull. Fac. Agri., Univ. of Cairo, 50(2): 283-298.

Sawsan, S.S. (2002). Physiological studieson the micropropagation of Solidago sp.Ph.D. Thesis, Faculty of Agriculture,Cairo University.

Sumit, M.; Uppeandra, D. and Meena, J. (2005). Organogenesis, embryogenesis, and synthetic seed production in Arnebia euchroma- a critically endangered medicinal plant of the Himalaya. In- VitroCellular- and - Developmental- Biology- Plant. 41 (3): 244-248.

Sydney Smith III (1931). "Digitalis glucosides". Journal of the Chemical Society 23 (3).

Trease, G.E. (1961). A text book of Pharmacognosy. London: Bailliere, Tindall and Cox. p. 513.

Varadarajan, M. ; Guruchandran, V. ; Nagarajan, S. M. ; Natarajan, E.; Jayakumar, R. T.; Kumar, B. N.; Ganesan, P. and Somasundaram, M. (2006). In vitro multiple shooting from the nodal explants of Boerhaavia diffusa L. using biopreserver-first report. Plant Archives. 6: 2, 491-493.

Warren B. Digitalis purpurea. Am J Cardiol . 2005; 95 (4) : 544.
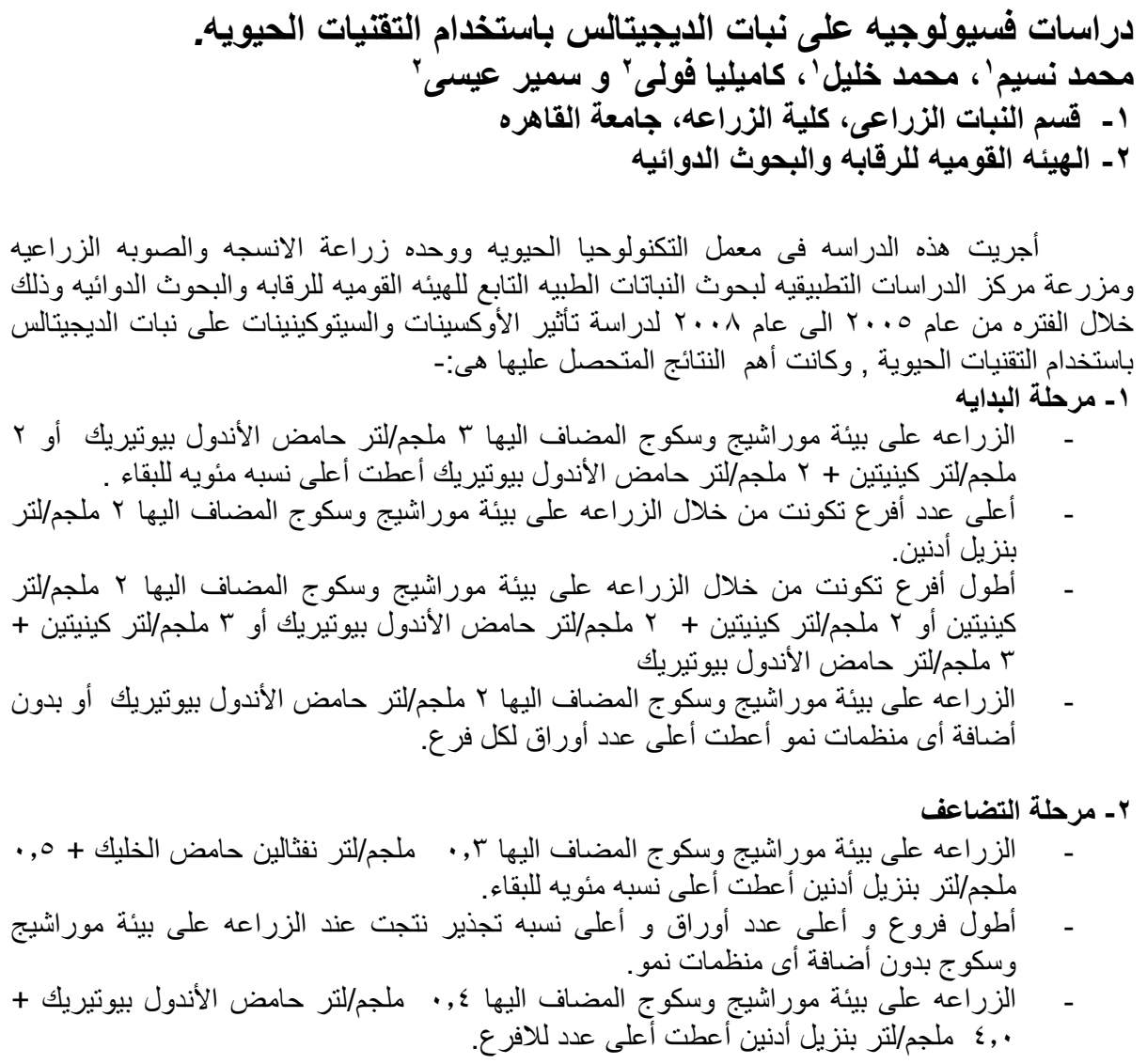


\section{Nesem, M. et al.}

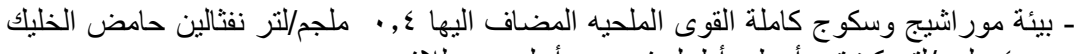

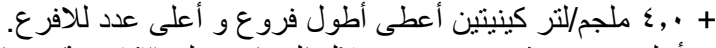

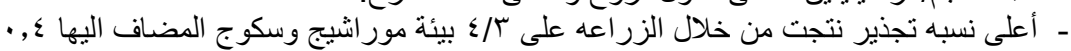
ملجم/لتر حامض الأندول بيوتيريك + , ,؛ ملجم/علتنر بنزيل أدنين.

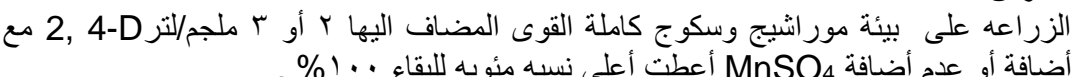
r- بكوين الكالوس

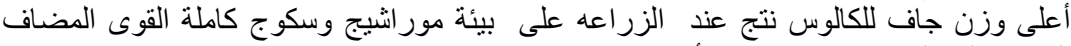

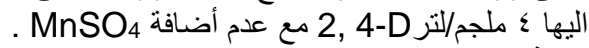

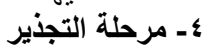

الزراعه على بيئة مور انثيج وسكوج كاملة القوى فى كل المعاملات أعطت أطول و أعلى نسبة

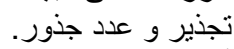
أعلى عدد جذور نتج عند الزراعه على بيئة موراشيج وسكوج المضاف اليها ه, . ملجم/لتر حامض الأندول بيوتيريك. أطول حذور. على بيئة مور اشيج وسكوج المضاف اليها r ملجم/لتر حامض الأندول بيوتيريك أعطى

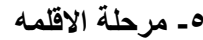
- بيئة البيت موس: الرمل ( (:) أعطت أعلى معدل بقاء (..1\%) و أطول أفرع و أعلى عدد للاوراق .

كلية الزراعة - جامعة المنصورة

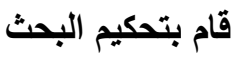
كلية الزراعة ـ جامعة القاهرة

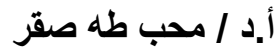

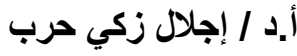

